\title{
Borrelia burgdorferi - en unik bakterie
}

\begin{abstract}
Sammendrag
Bakgrunn. Lyme-borreliose er en flåttoverført sykdom forårsaket av Borrelia burgdorferi. Antall rapporterte tilfeller stiger stadig både i Europa og USA. Flått som vektor for sykdommen spres til stadig nye områder. Sykdommen kalles nå «den nye store sykdomsimitator». Muligheten for feil diagnose og feil behandling kan være betydelig.
\end{abstract}

\begin{abstract}
Materiale og metode. Oversikten er basert på artikler funnet ved søk på egenskaper ved «Borrelia burgdorferi» i PubMed samt egen forskning innen feltet de siste 20 år.
\end{abstract}

Resultater. I de senere år har man oppdaget mange nye egenskaper ved Borrelia burgdorferi. Det viser seg at bakterien kan overleve selv om verten har et intakt immunforsvar. Bakterien kan disseminere tidlig i sykdomsforløpet til fjerntliggende områder, være anaerob, gjemme seg i nisjer, være intracellulær og uttrykke multimedikamentresistens. Den kan dekke seg med vertens materiale, foreta antigene forandringer, manipulere vertens immunapparat og forandre seg til inaktive cysteformer.

Det kan oppstå klinisk behandlingssvikt ved ethvert egnet antibiotikum.

Uten adekvat behandling kan infeksjonen føre til multisystemisk kronisk infeksjon. Erytema migrans er en klinisk diagnose. Ved kronisk sykdom er den kliniske diagnosen usikker. Antistoffutviklingen er sen og negativ serologisk prøve er hyppig, særlig tidlig i sykdomsfasen.

Fortolkning. Borrelia burgdorferi har mange muligheter til å unnslippe vertens forsvarsmekanismer og den har evnen til multimedikamentresistens. Det er behov for bedre diagnostiske metoder.

\section{$\emptyset y s t e i n$ Brorson}

oystein.brorson@siv.no

Mikrobiologisk avdeling

Sykehuset i Vestfold

3116 Tønsberg

Bakterien Borrelia burgdorferi er oppkalt etter den sveitsiskamerikanske zoologen Willy Burgdorfer (f. 1925). Spiroketen ble isolert og erkjent som årsak til Lyme-borreliose i 1982 (1).

Lyme-borreliose har de senere årene økt kraftig i forekomst både i USA og Europa. Dette skyldes sannsynligvis flere faktorer, både gjengroing av kulturlandskap, økning i hjortedyrbestanden, mildere klima og det at folk tilbringer mer tid ute i naturen (2). Det kan imidlertid ikke utelukkes at noe av årsaken til de hyppigere rapporterte tilfellene er mer oppmerksomhet rundt bakterien og bedre tester.

Hensikten med denne oversiktsartikkelen er å gi en oppdatering om de ulike egenskapene til B. burgdorferi.

\section{Materiale og metode}

Oversikten er basert på artikler om egenskaper ved bakterien funnet ved søk på «Borrelia burgdorferi» i PubMed samt egen forskning innen feltet de siste 20 år.

\section{Bakterien Borrelia burgdorferi}

B. burgdorferi sensu lato inndeles i minst 13 ulike genospesies. Lyme-borreliose forårsakes vanligvis av de fire genospesies av B. burgdorferi sensu lato: B. afzelii, B. garinii, B. burgdorferi sensu stricto og nylig funnet B. spielmanii $(3,4)$. Bakterien er en gramnegativ bevegelig spiroket (fig 1) som måler 0,18-0,3 × 15-30 $\mu \mathrm{m}$, er spiralsnodd og har 7-11 periplasmatiske flageller. Bevegelighetsrelaterte gener opptar over $6 \%$ av genomet til bakterien. De unike flagellene gjør at den kan bevege seg i viskøs væske og raskt disseminere (5). Bakterien kan være mikroaerofil eller anaerob, avhengig av genospesies og type. Den er også fakultativ intracellulær (6-9).

En av de mest slående egenskaper ved B. burgdorferi er det uvanlige genomet, som består av et lineært kromosom på 910 kilobasepar (kbp) og minst 12 lineære og ni sirkulære plasmider som varierer i lengde fra $5 \mathrm{kbp}$ til $54 \mathrm{kbp}$. Det er ikke kjent andre bakterier med så mange plasmider per celle. Mange av plasmidene kan mistes i kultur, men de resterende anses som svært viktige for bakterien og kalles gjerne «minikromo- somer». På alle DNA-endene av kromosomet er det telomerer som er lukket i den ene enden - som en hårnål. Dette er ikke kjent fra andre prokaryote celler. Lineært genom er også uhyre uvanlig blant mikroorganismene. Bakteriens genom inneholder bl.a. gener for hemolyse og DNA-reparasjon og antibiotikaeffluksproteiner. Bakterien inneholder ingen gener for cellulær biosyntesereaksjon, og den må derfor ha et meget komplekst medium for vekst. Noen av plasmidene koder for proteiner som er viktige virulensfaktorer, bl.a. det lineære plasmidet lp-28, som koder for antigen variasjon.

Mange av bakteriens gener er kodet for å produsere mer enn 100 lipoproteiner. Dette er flere enn hos andre kjente bakterier. Disse genene er for det meste plassert på plasmider. Proteinene er plassert på bakteriens overflate, hvor de kan komme i kontakt med verten. Noen av disse ytre membranantigenene er viktige for bakterien - de kalles OspA-F og protein 100 (10).

\section{Epidemiologi}

Lyme-borreliose er en vektoroverført sykdom. Vanligvis smittes mennesker av infisert flått. I Europa er det Ixodes ricinus som er kilden til borreliasmitte. I Norge er flåtten (fig 2) spesielt utbredt i de kystnære områder fra Hvaler til Helgeland, men de siste års milde vintre har nå ført til en fast bestand enkelte steder i innlandet. Lundelusen Ixodes uriae kan også være bærer av B. garinii. Det er derfor mulig at infisert sjøfugl kan spre smitte i arktiske områder via lundelusen (11). Flåttens spytt inneholder proteiner som er bedøvende, vasodilaterende, immunmodulerende og hindrer koagulering (12). Dette øker infeksiøsiteten. Andre insekter som klegg og stikkmygg kan også være bærere av spiroketen (13).

Spesielt virulente stammer synes stadig å øke i utbredelse både i Europa og USA (14).

\section{Hovedbudskap}

- Borrelia burgdorferi er en unik bakterie som har utviklet svært mange forsvarsmekanismer

- Den har evnen til å overleve alle typer antibiotika

- Dagens diagnostiske tester er mangelfulle og er bare et supplement i diagnostiseringen 


\section{Kliniske funn}

Det sikreste bevis for en borreliainfeksjon er det ekspanderende sirkulære røde utslettet som kalles erythema migrans, men ukarakteristiske utslett kan oppstå og føre til problemer med å diagnostisere sykdommen. Det kan også være forsinket utvikling av utslettet fra det normale (2-30 dager) til 100 dager (15), noe som kan resultere i sen behandling. Oftest er det hud, muskler, sentrale og perifere nerver, hjerne, hjerte og ledd som affiseres, men bakterien kan disseminere til alle vev og organer $(5,16)$.

B. afzelii og B. spelmanii fører oftest til ulike hudmanifestasjoner, B. garinii til nevrologiske symptomer og B. burgdorferi sensu stricto til leddproblemer, men de tre genospesies B. afzelii, B. garinii og B. sensu stricto kan gi alle symptomer $(3,4)$. Bakterien kalles nå ofte den «den nye store sykdomsimitatoren».

\section{Etablering av infeksjon}

To av bakteriens lipoproteiner (decorinbindende protein $\mathrm{A} \operatorname{og} \mathrm{B}$ ) binder seg til decorin, et proteoglykan som «dekorerer» kollagene fibre (17). Bakterien har også evnen til å binde seg til dermatansulfat, heparin, integrin og fibronectin. B. burgdorferi øker sin evne til invasivitet ved å degradere oppløselige og uoppløselige komponenter av vertens ekstracellulære matriks (18). Det er også vist at Lyme-spiroketen bruker feromoner som en viktig mekanisme til kommunikasjon, for å kontrollere proteinproduksjon og for å koordinere ulike funksjoner (19).

\section{Spesielle egenskaper}

B. burgdorferi produserer mange forskjellige såkalte Erp-proteiner på sin ytre membran som kan binde faktor $\mathrm{H}$ og faktor H-liknende protein (komplementhemmende molekyl) og på denne måten omgå den alternative komplementvei (20). Det gjelder B. afzelii og B. spielmanii og helt eller delvis $B$. burgdorferi sensu stricto, mens B. garinii hovedsakelig er følsom $(3,4)$. De ulike Erp-proteiner har affinitet til komplementhemmere hos ulike dyrearter, og bakterien kan dermed motstå komplementmediert drap og fagocytose hos hvilken som helst av de potensielle vertene den infiserer.

Under antistoffangrep kan B. burgdorferi mutere og foreta rearrangementer i DNA, noe som kan føre til antigenvariasjon. Det er særlig OspE som gjennomgår de store antigene variasjonene (21). Modifisering og nedregulering av andre ytre overflateproteiner (OspA, C), slik at de ikke bindes til beskyttende antistoffer, er også en egenskap som bakterien kan bruke for å omgå vertens forsvar. Dette er særlig viktig for bakterien tidlig i infeksjonsfasen.

Virulensegenskapene som fører til infeksjon anses for å være sterkt knyttet til ett av de ytre overflateproteinene (OspC) (22).

En av de mange utfordringer som bakterien utsettes for er de svært toksiske oksy- gen- og nitrogenforbindelsene som dannes $\mathrm{i}$ den infiserte organismen som svar på bakterieinvasjonen. Bakterien kan reagere på oksidativt stress ved å aktivere stressrelaterte gener for produksjon av enzymer som beskyttelse mot oksidasjon (23).

Sirkulerende immunkomplekser var et av de tidligste immunologiske fenomener som ble beskrevet ved Lyme-sykdom (24). Immunkomplekser kan finnes både i serum, spinalvæske og synovialvæske. Når sirkulerende immunkomplekser ikke blir godt nok fjernet av det retikuloendoteliale system, avsettes de i vev og organer og aktiverer komplementer, og dette kan føre til lokal inflammatorisk vevsdestruksjon (25). Immunkomplekser kan også medvirke til å forandre vertens forsvarsmekanismer via defekt Fcreseptor, slik at opsoniserte $\mathrm{B}$. burgdorferi ikke kan fjernes av monocytter.

B. burgdorferi er kjent for å produsere liposomliknende vesikler (blebs) som avstøtes fra den ytre membran. Antigenene OspA, B og D og protein-100 er inkorporert i disse «blebsene» og har affinitet til endotelceller. For at bakterien skal kunne overleve i det sirkulatoriske system er sannsynligvis fjerning av overflateantigener fordelaktig. Bakteriens «blebser» vil bli inkorporert i cytosol og i kjernen til dendrittiske celler, lymfocytter og fibroblaster. Dette fører til generering av CD8-positive T-celler, som vil kunne drepe visse celler og dermed stå bak en autoimmunliknende tilstand (26). «Blebsene» inneholder også en mitogen faktor for B-lymfocytter, som stimulerer til IgM-produksjon. De er også viktige penicillinbindende proteiner.

Mye oppmerksomhet er blitt rettet mot OspA. Dette er et helt spesielt protein som ikke er funnet ellers i naturen. Det kan bl.a. aktivere nukleærfaktor-kB og indusere mange cytokiner, adhesjonsmolekyler og nitrogenoksid. OspA er også en plasminreseptor, og den proteolytiske aktiviteten på celleoverflaten kan beskytte mot både komplementer og spesifikke antistoffer. En markert økning av OspA-reaktive CD-positive T-celler er også identifisert i inflammatoriske ledd hos antibiotikaresistente pasienter med Lyme-artritt og i spinalvæske hos pasienter med nevroborreliose.

Det er vist at B. burgdorferi-isolater fra pasienter kan konverteres til cysteformer in vivo under påvirkning av penicillin (27). Man har også lyktes med å konvertere cysteformer (fig 3) tilbake til bevegelige spiroketer, både in vitro og in vivo, og cystene har vist seg å være infeksiøse for mus (28-30). Cyster har oppgradert VlsE (Vmp-like sequence, expressed) og OspA-proteiner, og de har minst 20 nye antigener (31). Det er vist at Borrelia kan danne cyster når den utsettes for pencillin eller doksysyklin i konsentrasjoner svarende til MIC (minimal inhibitory concentration). Det nedreguleres mange proteiner, bl.a. p-66 (et viktig porin), og det uttrykkes flere inntil nylig ukjente proteiner

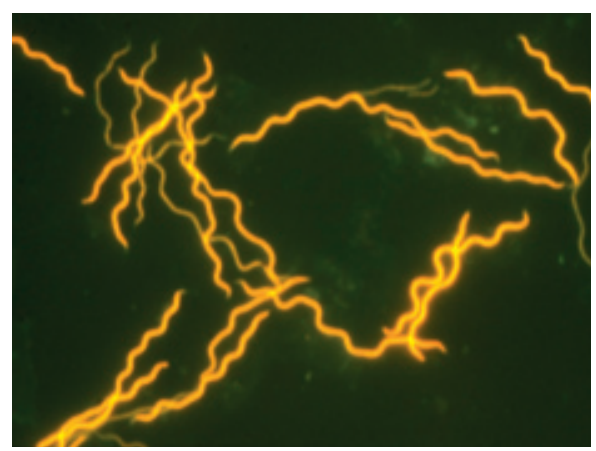

Figur 1 Borrelia burgdorferi dyrket i BSK-Hmedium og farget iakridinoransje. UV-mikroskopi, 2000 ganger forstørret. Foto Øystein Brorson

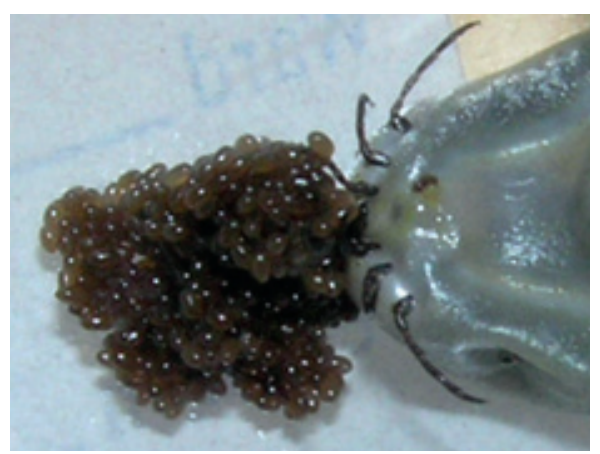

Figur 2 Fullsuget hunn som på våren har lagt egg. Størrelsen på flåtten er ca. $1 \mathrm{~cm}$. Foto Øystein Brorson

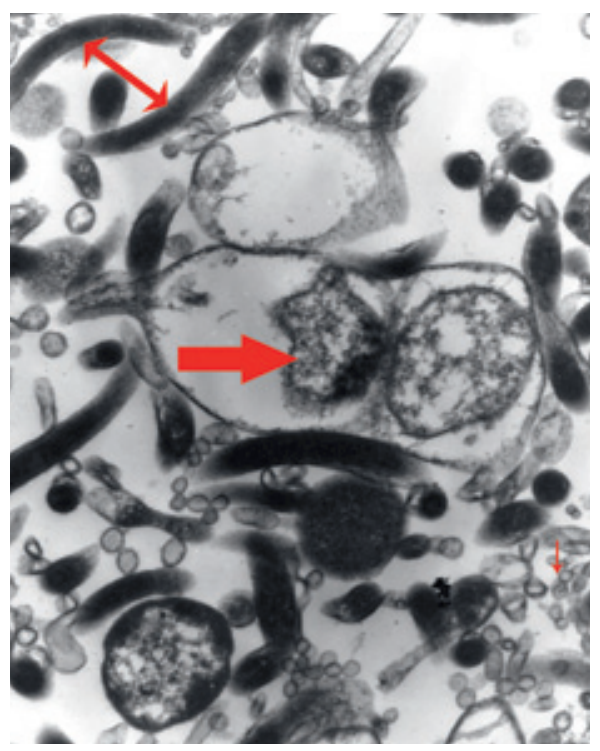

Figur 3 Borrelia burgdorfer-cyster fra destillert vann som er overført til BSK-H-medium og dyrket to uker ved $33^{\circ} \mathrm{C}$. Cysteformer i delingsfase (stor pill. Det ses også mange normale vanlige spiroke ter (tynn, lang pil) og «blebser» (liten, tynn pil). 15000 ganger forstørret. Foto Sverre-Henning Brorson

som er viktig for energi, aminosyresyntese, enzymatisk aktivitet og celledeling (32). Nylig er det vist ved studier i cellekultur og i biopsier fra hjernevev hos nevroborreliosepasienter at borreliacyster kan finnes både ekstra- og intracellulært og forårsake apoptose (33). 


\section{Vertens svar på infeksjonen}

Lipoproteiner, peptidoglykaner og sirkulerende immunkomplekser medvirker for en stor del til patogenesen ved Lyme-borreliose. Bakterien aktiverer forskjellige celler til å produsere betainterleukin-1-beta (IL-1$\beta)$, tumornekrosefaktor alfa (TNF- $\alpha$ ), interleukin-6 (IL-6) og interleukin-8 (IL-8). Ved nevroborreliose er det i spinalvæske vist økt sekresjon av borreliaspesifikk gammainterferon (INF- $\gamma$ ) og svært nedsatt sekresjon av interleukin-4 (IL-4) (34). Dette kan føre til vevsdestruksjon sekundært til immunrespons.

B. burgdorferi kan indusere en fire ganger økning i antall CD 16-NK-celler (naturlige drepeceller), men også en alvorlig hemming av NK-cellenes cytotoksiske evne (35). Dette i kontrast til andre bakterier, som er kjent for å aktivere NK-celler.

Nøytrofile granulocytter er viktige for fagocyttering av fremmende organismer, men OspB-produksjon hos B. burgdorferi kan hemme den fagocytterende evnen hos de nøytrofile granulocyttene og evnen til oksidativt drap. Nøytrofile granulocytter er de raskest bevegelige fagocytterende celler i kroppen, men nylig er det vist at B. burgdorferi kan bevege seg flere ganger raskere enn dem og dermed unngå fagocytose (36).

\section{Diagnostikk}

Serologiske analyser er viktige verktøy for å stille en sikker diagnose ved Lyme-borreliose, men sensitiviteten er lav i tidlig stadium av sykdommen. Anamnese og klinisk undersøkelse er derfor viktig for kunne å kunne stille en sikker diagnose.

Imidlertid dukker det stadig opp nye og forbedrede metoder - f.eks. «focus floating microscopy» (både horisontal og vertikal mikroskopering) av biopsimateriale, som ved erythema migrans har en sensitivitet på $98 \%$ og like høy spesifisitet som polymerasekjedereaksjon (PCR). Det er også nylig vist at ved å detektere $16 \mathrm{~S}$ rRNA-genet fra serum vil polymerasekjedereaksjonen få økt sensitivitet. Spesifikt borreliaantistoff bundet i sirkulerende immunkomplekser kan bidra til lav diagnostisk sensitivitet tidlig i forløpet av sykdommen. Påvisning av spesifikke immunkomplekser kan derfor være nyttig der det er klinisk mistanke og negativ serologisk prøve og kan muligens si noe om hvorvidt det foreligger aktiv infeksjon (37). Validerte undersøkelser for påvisning av spesifikke immunkomplekser er imidlertid foreløpig ikke tilgjengelig.

Den antigene heterogeniteten til de ulike stammene er stor. Dette kan gi opphav til lav diagnostisk sensitivitet, siden ofte bare én stamme av B. burgdorferi sensu lato blir benyttet i ELISA- og Western blot-tester. Nylig ble det utviklet en ELISA-test der man bruker et syntetisk peptid fra den konserverte delen av OspE (IR6) hos spiroketen. Denne testen har høy sensitivitet og spesifisitet, men analyseresultatet er også her avhengig av hvilke stamme som forårsaker infeksjonen.

Årsaker til lite antistoffproduksjon kan være at bakterien aktivt fester seg til, invaderer og dreper humane T- og B-lymfocytter (38), er fakultativ intracellulær $(6-9,33)$ og har evnen til å dekke seg med vertens materiale (19).

En studie av dyrkingspositive spinalvæsker viste at det var stor forskjell på serologiske og andre laboratoriemarkører dersom den infeksiøse stammen var B. garinii eller B. afzelii (39). Nye tester som kan være nyttig for spinalvæske er detektering av cytokinet CXCL13, som har vist seg å være forhøyet tidlig i forløpet ved nevroborreliose (40). En ny lymfocyttransformasjonstest (LTT-MELISA) ser ut til å korrelere med borreliainfeksjon og kan muligens si noe om klinisk bedring.

\section{Antibiotikaresistensmekanismer}

Behandling av Lyme-borreliose tidlig i sykdomsforløper er oftest vellykket hvis man følger de anbefalte retningslinjer, men kronisk infeksjon kan være vanskelig å behandle.

Mekanismer for bakteriens overlevelse er utilstrekkelig forstått, men at bakterien dekker seg med vertens materiale, har intracellulær lokalisering og lavbiologiske bakterieog cysteformer kan være av betydning (6-9, 33). Polymorfnukleære leukocytters produksjon av calprotectin, som fjerner tigjengelig sink og dermed hemmer celledelingen, kan gjøre bakterien resistent mot b-laktamantibiotika (41).

Bakteriens antibiotikafølsomhet skiller seg både fra grampositive og andre gramnegative bakterier. Den har naturlig resistens ovenfor aztreonam, teikoplanin, fucidinsyre, fluorokinoloner, aminoglukosider, cefaclor, loracarbef, nalidiksinsyre, trimetoprim-sulfametoksazol, fosfomycin og rifampicin (42). De stammer som er undersøkt så langt, viser svært variabel følsomhet overfor de ulike antibiotika. Den minste konsentrasjon av penicillin $\mathrm{G}$ som hemmer vekst av B. afzelii (MIC) er 100 ganger høyere enn for B. garinii (42).

Bakteriens efflukssystem kan utvikle seg til å omfatte utpumping fra bakteriecellen av mange ulike antibiotika, og kan dermed bidra til manglende effekt og persisterende infeksjon (43). Nye antibiotika som er resistente mot bakteriens efflukssystem kan da kanskje være en løsning.

Det er et kontroversielt spørsmål om cyster kan være årsak til persisterende infeksjon og reaktivering av sykdommen. Hydroksyklorokin og metronidazol har imidlertid vist seg å være cysteaktive in vitro $(44,45)$. Det er også kontroversielt om vedvarende symptomer etter gjennomgått Lyme-borreliose skriver seg fra persistent infeksjon eller er immunologisk betinget (46), men noen få studier viser at det er effekt av gjentatt og forlenget behandling (47-49).

\section{Vaksine}

Det er utviklet en OspA-vaksine for B. sensu stricto, men pga. bakterienes OspA-heterogenitet var ikke denne vaksinen effektiv mot B. afzelii og B. garinii. Den ga også flere bivirkninger og ble trukket tilbake fra markedet. Man arbeider imidlertid fortsatt med å utvikle en effektiv vaksine som kan dekke de vanlige genospesies. En ny rekombinant tetravalent vaksine basert på flere OspCtyper, som er under utvikling, vil dekke de sydomsfremkallende genospesies.

Oppgitte interessekonflikter: Ingen

\section{Litteratur}

. Burgdorfer W, Barbour AG, Hayes SF et al. Lyme disease - a tick-borne spirochetosis? Science 1982; 216: 1317-9.

2. Barbour AG, Fish D. The biological and social phenomenon of Lyme disease. Science 1993; 260: $1610-6$.

3. van Dam A, Kulper H, Vos K et al. Different genospecies of Borrelia burgdorferi are associated with distinct clinical manifestation of Lyme borreliosis. Clin Infect Dis 1993; 17: 708-17.

4. Herzberger $P$, Siegel $C$, Skerka $C$ et al. Human patogenic Borrelia spielmanii sp. now resist complement-mediated killing by direct binding of immune regulators Factor $\mathrm{H}$ and Factor $\mathrm{H}$-like protein 1. Infect Immun 2007; 75: 4817-25.

5. Luft BJ, Steinman CR, Neimark HG et al. Invasion of the central nervous system by Borrelia burgdor feri in acute disseminated infection. JAMA 1992; 267: $1364-7$.

6. Ma Y, Sturrock A, Weis JJ. Intracellular localization of Borrelia burgdorferi within human endothelial cells. Infect Immun 1991; 59: 671-8.

7. Wang P, Gartenhaus R, Sood SK et al. Detection of Borrelia DNA in circulating monocytes as evidence of persistent Lyme disease. Journal of Spirochetal and Tick-Borne Diseases 2000; 7: 16-9.

8. Georgilis K, Peacocke M, Klempner MS. Fibroblasts protect the Lyme disease spirochete, Borrelia burgdorferi, from ceftriaxone in vitro. J Infect Dis 1992: 166: 440-4

9. Peters DJ, Benach JL. Borrelia burgdorferi adherence and injury to undifferentiated neural cells in vitro. J Infect Dis 1997; 176: 470-7.

10. Casjens S. Borrelia genomes in the year 2000 J Mol Microbiol Biothechnol 2000; 2: 401-10.

11. Larsson C, Comstedt P, Olsen B et al. Firest record of Lyme disease Borrelia in the Arctic. Vector Borne Zoonotic Dis 2007; 7: 453-6.

12. Hovius JW, de Jong MA, den Dunnen J et al. Salp15 binding to DC-SIGN inhibits cytokine expression by impairing both nucleosome remodeling and mRNA stabilization. PLoS Pathog 2008; 4: e31.

13. Magnarelli LA, Anderson JF, Barbour AG. The etiologic agent of Lyme disease in deer flies, horse flies, and mosquitoes. J Infect Dis 1986; 154: 355-8.

14. Qui WG, Bruno JF, McCaig WD et al. Wide distribution of a high-virulence Borrelia burgdorferi clone in Europe and North America. Emerg Infect Dis 2008; 14: 1097-104

15. Carlson SA, Granlund H, Jansson $C$ et al. Charac teristics of erythema migrans in Borrelia afzelii and Borrelia garinii infections. Scand J Infect Dis 2003; 35: 31-3.

16. Wormser GP. Hematogenous dissemination in early Lyme disease. Wien Klin Wochenschr 2006 118: 634-7.

17. Fischer JR, Parveen N, Magoun L et al. Decorinbinding proteins $A$ and $B$ confer distinct mammalian cell type-specific attachment by Borrelia burg dorferi, the Lyme disease spirochete. Proc Natl Acad Sci USA 2003; 100: 7307-12.

18. Coleman JL, Roemer EJ, Benach JL. Plasmincoated Borrelia burgdorferi degrades soluble and insoluble components of the mammalian extracellular matrix. Infect Immun 1999; 68: 3929-36.

19. Stevenson B, von Lackum K, Wattier RL et al. Quorum sensing by the Lyme disease spirochete. Microbes Infect 2003; 5: $991-7$. 
20. Hellwage J, Meri T, Heikkilä T et al. The complement regulator factor $\mathrm{H}$ binds to the surface pro tein OspE of Borrelia burgdorferi. J Biol Chem 2001; 276: 8427-35.

21. Sung SY, McDovell JV, Carylon JA et al. Mutation and recombination in the upstream homology box-flanked ospE-related genes of the Lyme disease spirochetes results in the development of new antigenic variants during infection. Infect Immun 2000; 68: 1319-27.

22. Xu Q, Seemanapalli SV, McShan K et al. Constitutive expression of outer surface proteinC diminishes the ability of Borrelia burgdorferi to evade specific humoral immunity. Infect Immun 2006; 74: 5177-84.

23. Boylan JA, Posey JE, Gherardini FC. Borrelia oxidative stress response regulator, BosR: a distinctive $Z n$-dependent transcriptional activator. Proc Natl Acad Sci USA 2003; 100: 11684-9.

24. Hardin JA, Steere AC, Malawista SE. Immune complexes and the evolution of Lyme arthritis. Dissemination and localisation of abnormal C1q binding Activity. N Engl J Med 1979; 301: 1358-63.

25. Theofilopoulos AN, Dixon FJ. The biology and detection of immune complexes. Adv Immuno 1979; 28: 89-220.

26. Beermann C, Wunderli-Allenspach $H$, Groscurth $P$ et al. Lipoproteins from Borrelia burgdorfer applied in liposomes and presented by dendritic cells induce CD8+ T-lymphocytes in vitro. Cell Immunol 2000; 201: 124-31.

27. Preac Mursic V, Wanner G, Reinhardt S et al. Formation and cultivation of Borrelia burgdorferi spheroplast L-form variants. Infection 1996; 24 : 218-25

28. Brorson $\emptyset$, Brorson S-H. Transformation of cystic forms of Borrelia burgdorferi to normal, mobile spirochetes. Infection 1997; 25: 240-6.

29. Brorson $\emptyset$. Brorson S-H. In vitro conversion of Borrelia burgdorferi to cystic forms in spinal fluid, and transformation to mobile spirochetes by incubation in BSK-H medium. Infection 1998; 26: 44-50.
30. Gruntar I, Malovrh T, Murgia R et al. Conversion of Borrelia garinii cystic forms to motile spirochetes in vivo. APMIS 2001; 109: 383-8.

31. Alban SP, Johnson PW, Nelson DR. Serum-starvation induced changes in protein synthesis and morphology of Borrelia burgdorferi. Microbiology 2000; 146: 119-27.

32. Hunfeld KP, Burg S, Hanssen-Hübner $\mathrm{C}$ et al. Changes in the expression pattern of structural proteins after exposure of Borrelia burgdorferi to penicillin $G$ and doxycycline. Int J Med Microbiol 2008; 298 (suppl 1): 325-32.

33. Miklossy J, Kasas S, Zurn AD et al. Persisting atypical and cystic forms of Borrelia burgdorferi and local inflammation in Lyme neuroborreliosis. J Neuroinflammation 2008; 5: 40.

34. Ekerfelt C, Ernerudh J, Bunikis J et al. Compartmentalization of antigen specific cytokine responses to the central nervous system in CNS borreliosis: secretion of INF-g predominates over IL-4 secretion in response to outer surface proteins of Lyme disease Borrelia spirochetes. J Neuroimmunol 1997: 79: 155-62.

35. Hartiala P. Hytönen J, Suhonen J et al. Borrelia burgdorferi inhibits human neutrophil functions. Microbes Infect 2008; 10: 60-8

36. Malawista SE, ChevanceAB. Clocking the Lyme spirochete. PLoS ONE 2008; 3: e1633.

37. Schutzer SE, Coyle PK, Reid P et al. Borrelia burg dorferi-specific immune complexes in acute Lyme disease. JAMA 1999; 282: 1942-6.

38. Dorward DW, Fischer ER, Brooks DM. Invasion and cytophatic killing of human lymphocytes by spirochetes causing Lyme disease. Clin Infect Dis 1997; 25 (suppl 1): 52-8.

39. Strle F, Ruzic-Sabljic E Cimperman J et al. Comparision of findings for patients with Borrelia garinii and Borrelia afzelii isolated from cerebrospinal fluid. Clin Infect Dis 2006; 43: 704-10.

40. Ljøstad U, Mygland A. CSF B-lymphocyte chemoattractant (CXCL13) in the early diagnosis of acute Lyme neuroborreliosis. J Neurol 2008; 255: 732-7.
41. Lusitani D, Malawista SE, Montgomery RR. Calprotectin, an abundant cytosolic protein from human polymorphonuclear leucocytes, inhibits the growth of Borrelia burgdorferi. Infect Immun 2003 71: 4711-6.

42. Hunfeld KP, Brade V. Antimicrobial susceptibility of Borrelia burgdorfri sensu lato: What we know, what we don't know, and what we need to know. Wien Klin Wochenschr 2006; 118: 659-68.

43. Bunikis I, Denker K, Östberg Y et al. S. An RNDtype efflux system in Borrelia burgdorferi is involved in virulence and resistance to antimicrobial compounds. PLoS Pathog 2008; 4: e1000009.

44. Brorson O, Brorson S-H. An in vitro study of the susceptibility of mobile and cystic form of Borrelia burgdorferi to metronidazole. APMIS 1999; 107: 566-76.

45. Brorson O, Brorson S-H. An in vitro study of the susceptibility of mobile and cystic forms of Borrelia burgdorferi to hydroxychloroquine. Int Microbiol 2002; 5: 25-31.

46. Klempner MS, Hu LT, Evans J et al. Two controlled trials of antibiotic treatment in patients with persistent symptoms and a history of Lyme disease. N Engl J Med 2001; 345: 85-92.

47. Donta ST. Late and chronic Lyme disease. Med Clin North Am 2002; 86: 341 -9.

48. Oksi J, Marjamäki M, Nikoskelainen J et al. Borrelia burgdorferi detected by culture and PCR in clinical relapse of disseminated Lyme borreliosis. Ann Med 1999; 31: 225-32

49. Cameron D. Severity of Lyme disease with persistent symptoms. Insights from a double-blind placebo-controlled clinical trial. Minerva Med 2008; 99: 489-96.

Manuskriptet ble mottatt 2.7. 2008 og godkjent 20.8. 2009. Medisinsk redaktør Erlend Hem. 